\title{
ОБСЕ в современной системе европейской безопасности
}

\section{Гарипов P.WI.*}

Организация по безопасности и сотрудничеству в Европе (ОБСЕ) это организация, в составе 55 государств-участников занимающаяся обеспечением безопасности. Имея более 3000 сотрудников, работающих в 19 миссиях на местах и в пяти институтах, составляющих в совокупности единую региональную организацию по безопасности, ОБСЕ в своем регионе служит главным инструментом раннего предупреждения, предотвращения конфликтов, регулирования кризисов и постконфликтного восстановления' .

Организация по безопасности и сотрудничеству в Европе занимается обеспечением:

- раннего предупреждения и предотвращения конфликтов;

- свободы, плюрализма и независимости СМИ;

- мер укрепления доверия и безопасности;

- демократических избирательных процессов;

- прав человека и гражданского общества;

- контртеррористических мер;

- деятельности высокопрофессиональной и пользующейся уважением населения полиции;

- надлежащей практики государственного управления и верховенства закона;

- деятельности в области экономики и окружающей среды;

- мер по контролю над вооружениями, включая легкое и стрелковое оружие.

Сегодня, когда в Европе покончено с конфронтацией и расколом на два противостоящих лагеря, цели ОБСЕ (ранее - СБСЕ), изложенные в Хельсинкском заключительном акте 1975 года, остаются не менее актуальными, чем 29 лег тому назад. ОБСЕ продолжает внутренне эволюционировать, подвергая свою работу на местах критической пере-

- Гарипов Руслан Шавкатович - аспирант кафедры конституционного и международного права КГУ.

' См.: Ежегодный доклад за 2002 год о деятельности ОБСЕ. Вена. 2003. ОБСЕ. С. 2. 
оценке и стремясь находить оптимальные решения для урегулирования многочисленных конфликтов в современном мире. ОБСЕ придает большое значение развитию отношений с другими международными организациями, научными учреждениями, региональными организациями и НПО, видя в данном сотрудничестве верный и эффективный путь к решению проблем предотврашения конфликтов, регулирования кризисов и постконфликтного восстановления.

Организация по безопасности и сотрудничеству в Европе была образована в рамках положений главы VIII Устава ОOH, где предусматривается возможность существования «региональных органов», практически региональных организаций, наделенных полномочиями по мирному разрешению «местных споров», то есть споров между государствами - участниками таких организаций. В этом контексте в главе VIII Устава ООН говорится, что региональные соглашения и организации могут вносить значительный вклад в усилия Совета Бе3опасности ООН по обеспечению мира и безопасности ${ }^{2}$.

ОБСЕ является единственной организацией, которая включает в себя все европейские государства, Соединенные Штаты Америки и Канаду, которые несут совместную ответственность за безопасность в Европе. Благодаря этому уникальному положению она незаменима.

Организация по безопасности и сотрудничеству в Европе в качестве регионального соглашения по смыслу главы VIII Устава ООН заявила о себе как о главном инструменте в своем регионе для раннего предупреждения, предотвращения конфликтов, урегулирования кризисов и постконфликтного восстановления ${ }^{3}$.

С точки зрения международного права (de jure) ОБСЕ не является полноценной международной организацией, так как не имеет своего Устава, как, например, ООН. С практической же точки зрения (de facto) ОБСЕ является международной организацией с широкими возможностями и огромным потенциалом в области обеспечения международной безопасности. То есть ОБСЕ занимает уникальное положение. С одной стороны, у нее нет формального международно-правового статуса, а все ее решения являются политически обязывающими, но не имеют обязательной юридической силы. Вместе с тем у нее есть большинство атрибутов, обычно присущих международным организаци-

\footnotetext{
${ }^{2} \mathrm{C}_{\mathrm{M}}$.: Klaas Van Walraven. Early worning and conflict prevention. Limitations and Possibilities. 1998. Kluwer Law International. P. 127.

${ }^{3} \mathrm{C}_{\mathrm{M}}$.: Arie Bloed. The Challenges of Change. The Helsinki Summit of the OSCE and its Aftermath. 1994. Kluwer Academic Publishers. P. 30.
} 
ям: постоянно действуюшие руководящие органы, постоянные штабквартира и институты, постоянный персонал, регулярное финансирование и отделения на местах. Большинство принимаемых в ней документов, решений и обязательств облечены в юридическую форму, а их толкование требует знакомства с международно-правовыми принципами и нормативной методологией права международных договоров. Даже то, что положения, принятые в рамках ОБСЕ, не имеют обязательной юридической силы, не снижает их эффективности. Подписанные на высшем политическом уровне, они по праву могут считаться не менее весомыми, чем положения любых международно-правовых актов.

Последнее время рассматривается вопрос о подготовке и подписании всеми государствами-участниками конвенции по ОБСЕ, которая могла бы стать Уставом ОБСЕ. Это необходимо для придания организации нового статуса и усиления потенциала ОБСЕ.

Организация по безопасности и сотрудничеству в Европе была создана по инициативе СССР в 1975 году и называлась «Совещание по безопасности и сотрудничеству в Европе». Главная цель Совешания заключалась в урегулировании спорных вопросов между капиталистическим Западом и социалистическим Востоком. Однако с прекращением холодной войны наступил поворотный момент в деятельности Совещания, когда на Парижской встрече на высшем уровне в ноябpe 1990 года СБСЕ был задан новый курс. В Парижской хартии для новой Европы перед СБСЕ была поставлена задача внести свой вклад в управление процессом исторических перемен в Европе и дать ответ на новые вызовы, возникающие после окончания холодной войны, создав постоянные институты и оперативный потенциал ${ }^{4}$.

В контексте Парижской встречи на высшем уровне, в ноябре 1990 года, было выработано важное соглашение по контролю над вооружениями - Договор об обычных вооруженных силах в Европе. К настоящему моменту в актив военно-политического измерения СБСЕ/ОБСЕ вошло и несколько других важных договоров, касающихся военной безопасности, в том числе Договор по открытому небу 1992 года и Венские документы 1990, 1992, 1994 и 1999 годов, а также имеющий ключевое значение Документ о легком и стрелковом оружии (2000 год).

Все документы ОБСЕ, кроме двух договоров, принятых в рамках организации (ДОВСЕ и Открытое Небо), имеют только политически-

${ }^{4} \mathrm{CM}$.: Ingo Peters. New Security Challenges: the adaptation of international institutions. 1996 Lit Verlag. St. Martin's Press, New Yourk. P. 98-99. 
обязательный характер. И зачастую на практике происходит расхождение между политически-обязательными договоренностями в рамках ОБСЕ и внутренним законодательством государств-участников. Например, после принятия государством политических обязательств докладывать о свонх вооруженных силах, о проводимых военных учениях и т.д. возникают внутренние акты (юридически обязательные) о государственной тайне, о неразглашении секретных данных, о запрете на доступ к военной информации и т.д.

Что касается договоров, подписанных в рамках ОБСЕ - ДОВСЕ и Открытое Небо, хотя они и носят юридически-обязательный характер для государств-участников, но отражают потребности давно прошедших дней. Данные соглашения были подписаны в годы холодной войны и были призваны уравновесить вооруженные силы двух противостоящих друг другу блоков - НАТО и ОВД. ${ }^{5}$

Стремясь адаптироваться к переменам, вызванным окончанием холодной войны, особенно распадом Организации Варшавского договора, государства-участники поручили своим делегациям в Совместной консультативной группе по ДОВСЕ в мае 1996 года начать консультации, направленные на улучшение действия Договора в изменившейся обстановке в области безопасности в Европе. Эти консультации были завершены в ноябре 1999 года на Стамбульской встрече глав государств и правительств стран - участниц ОБСЕ, где подписали Соглашение об адаптации Договора об Обычных вооруженных силах в Европе, открывшее возможность присоединения к Договору для государств, не являющихся и никогда не являвшихся членами НАТО или Варшавского пакта. Адаптированный договор также положил конец расколу Европы на два блока, определив для каждого государства индивидуальные предельные уровни вооружений вместо установления предельных групповых уровней.

И хотя договор об Обычных Вооруженных Силах в Европе и был пересмотрен, в нем имеется ряд недостатков. Это в частности то, что он действует только на европейской части региона ОБСЕ (только 30 из 55 стран-участников подписали данный договор), например США в данном соглашении не принимает участия, Россия и Казахстан охватываются договором только частично (в России - до Уральских гор), в Турции договор недействителен в той части, где преимушественно проживают курды.

${ }^{5}$ СM.: Graeme P. Auton. Arms control and European security. 1989. Printed in the USA. P. 107-108. 
В Париже в 1990 году были созданы следующие постоянно действующие органы: Совет министров иностранных дел, Комитет старших должностных лиц, Секретариат, Центр по предотвращению конфликтов, Бюро по свободным выборам, Парламентская ассамблея. Были развернуты миссии. Работа Совещания приобрела более систематизированный характер ${ }^{6}$.

На Будапештской встрече на высшем уровне 1994 года, участники которой констатировали, что СБСЕ уже не является просто Совещанием, они приняли решение переименовать его в Организацию по безопасности и сотрудничеству в Европе. Это придало работе Организации новый политический импульс и одновременно стало отражением того пути институционального развития, который был пройден ею с момента окончания холодной войны.

На Лиссабонской встрече на высшем уровне в 1996 году была осуществлена дальнейшая проработка вопроса о ключевой роли ОБСЕ в деле укрепления безопасности и стабильности. Эта встреча также стимулировала разработку в ОБСЕ принятой на Стамбульской встрече на .высшем уровне 1999 года Хартии европейской безопасности, которая предусматривает совершенствование оперативных возможностей Организации. Кроме того, в Стамбуле 30 государств - участников ОБСЕ подписали пересмотренный Договор об обычных вооруженных силах в Европе.

ОБСЕ воплощает принцип, согласно которому безопасность носит всеобъемлющий характер и должна быть организована на основе партнерства государств. Организацию отличает присущий только ей подход к обеспечению безопасности, являющийся одновременно всесторонним и основанным на сотрудничестве. Всесторонним в том смысле, что он охватывает три измерения безопасности - человеческое, военно-политическое и экономико-экологическое, в силу чего ОБСЕ занимается широким кругом вопросов, связанных с упрочением безопасности, включая контроль над вооружениями, превентивную дипломатию, меры укрепления доверия и безопасности, права человека, демократизацию, а также экономическую и экологическую безопасность. А сотрудничество заключается в том, что государства, участвующие в деятельности ОБСЕ, имеют одинаковый статус и не связаны договорными обяза-

${ }^{6} \mathrm{CM}_{\text {M.: }}$ Ingo Peters. New Security Challenges: the adaptation of international institutions. 1996 Lit Verlag. St. Martin's Press, New Yourk. P. 206-207. 
тельствами, в силу чего решения принимаются на основе консенсуса и носят политически, а не юридически обязательный характер ${ }^{7}$.

Принцип консенсуса является отличительной чертой ОБСЕ, ОН не характерен больше ни для одной международной организации. Данный принцип заставляет стороны находить компромисс и выносить общеприемлемые решения, не позволяя более сильным государствам диктовать свои условия слабым.

В научной литературе часто можно встретить негативное отношение к принципу консенсуса, так как он не позволяет принять решение быстро и всегда вызывает продолжительные дискуссии. Предлагают оставить голоса основных государств-участников, а остальных объединить в различные блоки по интересам. И сейчас уже существуют такие позиции, как консенсус минус один и консенсус минус два. Однако принцип консенсуса позволяет даже не выносить на обсуждение различные предложения, если уже заранее известно, что по ним будут противники ${ }^{8}$.

Важным моментом в архитектуре европейской безопасности является сотрудничество ОБСЕ с другими международными организациями. Необходимо исключить дублирование функций ОБСЕ, ЕС, НАТО и ООН. Для этого надо тесно координировать свои действия и решения, определить поле деятельности для каждой из организаций, исходя из имеющихся в их потенциале механизмов и средств обеспечения международной безопасности. Для ОБСЕ в этой общей системе обеспечения мира и стабильности можно выделить нишу политических переговоров при урегулировании межнациональных споров и конфликтов. Например, принятие каких-либо документов путем консенсуca, так как у ОБСЕ имеется огромный опыт именно в этой области и нет других эффективных механизмов, которыми обладают НАТО и ЕС ${ }^{9}$.

Главным для ОБСЕ были и остаются исключение применения силы, раннее предупреждение конфликтов и урегулирование кризисов политическими средствами, принятие средств предотвращения конфликтов и мирное урегулирование споров. Все это входит в понятие превентивной дипломатии. Именно такой подход закреплен в решениях «Хельсинки-2», где сказано, что операции ОБСЕ по поддержанию мира

\footnotetext{
${ }^{7}$ См.: Merrills J.G. International dispute settlement. 1998. Cambridge University Press. P. 82.

${ }^{8}$ См.: Тренин Д. Россия и основные институты безопасности в Европе: вступая в XXI век. М., 2000. Центр Карнеги. С. 194.

${ }^{9} \mathrm{CM}$.: Michael Bothe, Natalino Ronzitti, Allan Rosas. The OSCE in the maintenance of peace and security. 1997. Kluwer Law International. P. 514.
} 
не будут предусматривать принудительных действий, а последние рассматриваются как временная мера, пока не будет налажен надежный механизм своевременного предупреждения возникновения конфликтов и мирного урегулирования споров и разногласий. А до тех пор ОБСЕ будет обращаться за помощью к ООН, ЕС и НАТО в контексте необходимых шагов по поддержанию мира.

В связи с изменившейся обстановкой на международной арене (распад противоборствующих блоков) вызовы в области безопасности кардинально изменились. Если ранее ОБСЕ успешно вела переговоры между Западом и Востоком и была эффективным средством предотвращения конфликтов, то сейчас организации пришлось подстраиваться под новые вызовы в области международной безопасности. Это торговля людьми, наркотиками, международный терроризм и т.д. Все измерения безопасности пересекаются: например, если не уничтожить устаревшие боезапасы, то наносится непоправимый вред окружающей среде. Поэтому необходимо постоянно держать руку на пульсе времени и решать проблемы по мере их появления в комплексе, не отрывая друг от друга.

Те результаты, которых добилась ОБСЕ за долгие годы работы, можно потерять, если постоянно не вести переговоры и не подстраиваться под изменившиеся условия окружающего нас мира.

Главный результат - это доверие между государствами. Необходима прозрачность и доступность информации, относящейся к военной области. Огромный скачок был сделан в этом направлении со времен холодной войны до сегодняшних дней.

Сейчас ОБСЕ занимает уникальное место среди европейских институтов безопасности. Оно определяется широтой ее членского состава, ее всеобъемлющим подходом к безопасности, имеющимися у нее инструментами предотврашения конфликтов, глубоко укоренившейся традицией открытого диалога и формирования консенсуса, а также наличием отлаженных механизмов сотрудничества с другими международными организациями. 